\title{
Antimicrobial resistance, diarrheagenic and avian pathogenic virulence genes in Escherichia coli from poultry feed and the ingredients
}

J.J. Puño-Sarmiento

https://orcid.org/0000-0002-8470-0113 G. Nakazato

https://orcid.org/0000-0001-8624-795X L.F.D. Lopes

[Resistência antimicrobiana, genes de virulência diarreiogênicos e patogênicos para aves em Escherichia coli isoladas de ingredientes e ração de frangos]

https://orcid.org/0000-0002-2438-0226 L.A.G. Balsan

https://orcid.org/0000-0003-4837-4741

J.M. Rossato $^{1}$, B.G. Brito ${ }^{2}$, R.K.T. Kobayashi ${ }^{3}$, V.L. Koga ${ }^{4}$, J.J.P. Sarmiento ${ }^{4}$, T.T. Grassotti G. Nakazato ${ }^{3}$, L.F.D. Lopes $^{5}$, L.A.G. Balsan ${ }^{5}$, T.T. Grassotti ${ }^{2}$, K.C.T. Brito ${ }^{2 *}$

https://orcid.org/0000-0003-1166-514X K.C.T. Brito

${ }^{1}$ Programa de pós-graduação - Instituto de Pesquisas Veterinárias Desidério Finamor https://orcid.org/0000-0002-0429-8276 \author{
Eldorado do Sul, RS \\ ${ }^{2}$ Instituto de Pesquisas Veterinárias Desidério Finamor - Eldorado do Sul, RS \\ ${ }^{3}$ Universidade Estadual de Londrina - Londrina, PR \\ ${ }^{4}$ Programa de pós-graduação - Universidade Estadual de Londrina - Londrina, PR \\ ${ }^{5}$ Universidade Federal de Santa Maria - Santa Maria, RS
}

\begin{abstract}
Diarrheagenic (DEC) and avian pathogenic Escherichia coli (APEC) are associated with intestinal and extra-intestinal infections (ExPEC), respectively. We aimed to analyze the antimicrobial susceptibility, gene encoding virulence factors associated to DEC and APEC, and phylogenetic classification in E. coli isolated from 320 samples of feed and ingredients. Antimicrobial susceptibility was performed using the disk diffusion method and Multiple Antibiotic Resistance (MAR) Index and Multi-Drug Resistance (MDR) were calculated. Phylogenetic classification was performed on samples harboring DEC and/or APEC virulence-associated genes. A total of $110 \mathrm{E}$. coli strains were isolated in $15 \%(49 / 320)$ of the evaluated inputs ( $n=13$ vegetable meal; $n=33$ animal meal, $n=3$ feed). In general, the isolates showed the highest rates of antimicrobial resistance to sulfonamide and cefazolin and 18\% (20/110) were multi-drug resistant. MAR index of feed samples was the highest (0.467). Six and five strains had APEC and DEC virulence-associated genes, respectively, and belonging to phylogenetic groups A and B1. These findings point to the need for strict microbiological control during the production process of these foods.
\end{abstract}

Keywords: poultry production, animal feed, antimicrobials, virulence, resistance

\section{RESUMO}

Escherichia coli diarreiogênicas (DEC) e patogênicas para aves (APEC) são associadas a infecções intestinais e extraintestinais (ExPEC), respectivamente. O objetivo do presente trabalho foi avaliar a sensibilidade antimicrobiana, a presença de genes que codificam os fatores de virulência relacionados à DEC e APEC, e a classificação filogenética em E. coli isoladas de 320 amostras de ração para frangos e ingredientes. A sensibilidade antimicrobiana foi determinada pelo método disco-difusão e calculou-se o índice de resistência múltipla aos antimicrobianos (IRMA) e a resistência a múltiplas drogas (MDR). Nas amostras que possuíam genes de virulência relacionados à DEC elou APEC, foi realizada a classificação filogenética. Foram isoladas 110 amostras de E. coli em 15\% (49/320) dos insumos avaliados (n=13 farelos vegetais; $n=33$ farinhas de origem animal; $n=3$ rações). De forma geral, os isolados apresentaram as maiores frequências de resistência antimicrobiana à sulfonamida e à cefazolina e 18\% (20/110) foram resistentes a múltiplas drogas. O IRMA das rações foi o mais alto (0,467). Os genes que codificam fatores de virulência associados à APEC e DEC foram detectados em seis e cinco isolados, respectivamente, pertencentes aos grupos filogenéticos $A$ e B1. Os resultados demonstram a necessidade de rigoroso controle microbiológico durante o processo de produção desses alimentos.

Palavras-chave: aves de produção, alimentos para animais, antimicrobianos, virulência, resistência

Recebido em 19 de outubro de 2017

Aceito em 19 de abril de 2019

*Autor para correspondência (corresponding author)

E-mail: kelly_tagliari@hotmail.com 


\section{INTRODUCTION}

The poultry industry is a sector of great importance to the world and Brazil is one of the protagonists in production of feed and leading exporter of poultry animal protein. The quality of animal feed goes a long way to determine the livestock produced to be used for human consumption. Feed and raw materials can be sources of pathogenic agents in animal production, causing several diseases and consequently significant losses to producers and to the economy (Geornaras et al., 2001). In avian, Escherichia coli inhabit the gastrointestinal and upper respiratory tract. However, some strains are associated with several diseases in poultry and humans, as diarrheagenic (DEC) and extraintestinal (ExPEC) pathogenic E. coli. DEC is responsible for intestinal infections and can be divided into eight pathotypes - enteropathogenic (EPEC), enterohemorrhagic (EHEC), enterotoxigenic (ETEC), enteroaggregative (EAEC), enteroinvasive (EIEC), diffusely adherent (DAEC), adherent invasive (AIEC) and enteroaggregation producer of Shiga toxin (STEAEC). Diarrhea is a public health concern, especially in children, and EPEC and EAEC are the main pathotypes related to diarrhea in Brazil (Aranda et al., 2007). Avian pathogenic E. coli (APEC) can cause extra-intestinal diseases, called colibacilosis, especially in the respiratory tract, cellulitis, or systemic infections that result in large economic losses in the avian industry (Dho-Moulin and Fairbrother, 1999).

Pathogenicity is associated with the presence of various virulence characteristics, such as adhesion, iron acquisition, hemolysins, aerobactins and serum resistance, which are expressed by virulence genes located in plasmids or chromosomal regions, called pathogenicity islands (Ahmed et al., 2013). The improper use of antimicrobials can contribute to the selection of resistant strains and the chances to transfer characteristics of resistance to other strains that do not possess them, thereby compromising treatments required for future infection.

There is still little information about microbiological contamination of feed applied in poultry production, in Brazil and worldwide. The use of contaminated feed supplies may favor the persistence of potentially pathogenic microorganisms in the industry, which shows the importance of continuous microbiological monitoring. The aim of our study was to analyze the occurrence of contamination by $E$. coli in feed and the ingredients used in poultry production, the presence of virulence genes of APEC and DEC, phylogenetic group and the antimicrobial susceptibility.

\section{MATERIAL AND METHODS}

A total of 320 samples of poultry feed and ingredients (animal meal $n=252$, vegetable meal $\mathrm{n}=31$, and feed $\mathrm{n}=37$ ) were randomly collected by five rendering plants and cereal grain industries of Rio Grande do Sul, Brazil, in 2014 (Figure 1). The collection of samples and the bacterial isolation followed American Public Health Association (Compendium, 2001). Colonies suspected to be E. coli on Eosin Methylene Blue Agar (EMB) were characterized by Gram staining and biochemical testing using Sulfide-Indol-Motility (SIM), Triple Sugar Iron Agar (TSI), Lysine Iron Agar (LIA), agar Simmons Citrate and Urea.

Antimicrobial susceptibility was performed using the standard disk diffusion method recommended by the Clinical and Laboratory Standards Institute (Methods, 2012). Antimicrobials used included $5 \mu \mathrm{g}$ of each of enrofloxacin, and ciprofloxacin, $10 \mu \mathrm{g}$ of each of norflaxocin, gentamicin, and ampicillin, $30 \mu \mathrm{g}$ of each of cefazolin, cefotaxime, cefoxitina, ceftazidime, neomycin, florfenicol, tetracycline, nalidixic acid, doxycycline, and chloramphenicol, $300 \mu \mathrm{g}$ of each of nitrofurantoin, and sulphonamide, $1.25 / 23.75 \mu \mathrm{g}$ of trimethoprim-sulphonamide, and $20 / 10 \mu \mathrm{g}$ of amoxicillin-clavulanic acid. $E$. coli strain ATCC 25922 was used as a quality control for antimicrobial susceptibility testing. The strains were categorized as susceptible, intermediate or resistant. The multiple resistance profile characteristic was identified in the isolates when observed resistance to three or more classes of drugs. For each E. coli isolate, Multiple Antibiotic Resistance (MAR) Index was calculated as the number of antimicrobials to which test isolate displayed resistance divided by total number of antimicrobials to which the test microorganism has been evaluated for susceptibility (Krumperman, 1983). 
Strains were evaluated for the presence of five genes considered predictors of virulence of APEC (iroN, ompT, hlyF, iss and iutA) by pentaplex PCR (Johnson et al., 2008). Virulence genes of DEC were evaluated by three multiplex PCR: stxl, stx2, eaeA and ehxA (Paton and Paton, 1998); elt and ipaH (Aranda et al., 2007); aap, aggR and AA probe (Cerna et al., 2003). Phylogenetic classification groups (A, B1, B2, or D) was performed on samples harboring DEC and/or APEC virulence-associated genes by PCR technique according to the method of Clermont et al. (2000) based on analysis of presence of the chuA and yjaA genes and the DNA fragment (TSPE4.C2).

Statistical analyses were performed by comparisons of frequencies among different groups by the Chi square test. Values were considered significant when $\mathrm{P} \leq 0.05$. The relationship between MAR and the type of input was performed using the Kruskal-Wallis test, and Dunn's multiple comparisons test. Results were significant when $\mathrm{P} \leq 0.05$. The statistical programs used were Statistical Analysis System (SAS) version 9.2 and GraphPad Prism 6.

\section{RESULTS AND DISCUSSION}

From 320 samples, 49 (15\%) tested positive for $E$. coli. The distribution of feed and ingredients that tested positive for $E$. coli are depicted in Figure 1. The expected contamination percentage was $20 \%$, but the observed percentage for vegetable meal was $41.94 \% \quad(n=13)$, with a significant difference (Chi-square 9.323, 1, $\mathrm{P}<0.0023)$; animal meal was $13.10 \%(\mathrm{n}=33)$, with a significant difference (Chi-square 7.509, $1, \mathrm{P}<0.0061)$; and feed $8.11 \%(\mathrm{n}=3)$. Strains of E. coli $(\mathrm{n}=110)$ were isolated from positive samples of vegetable meal $(n=18)$, animal meal $(n=74)$ and feed $(n=8)$.
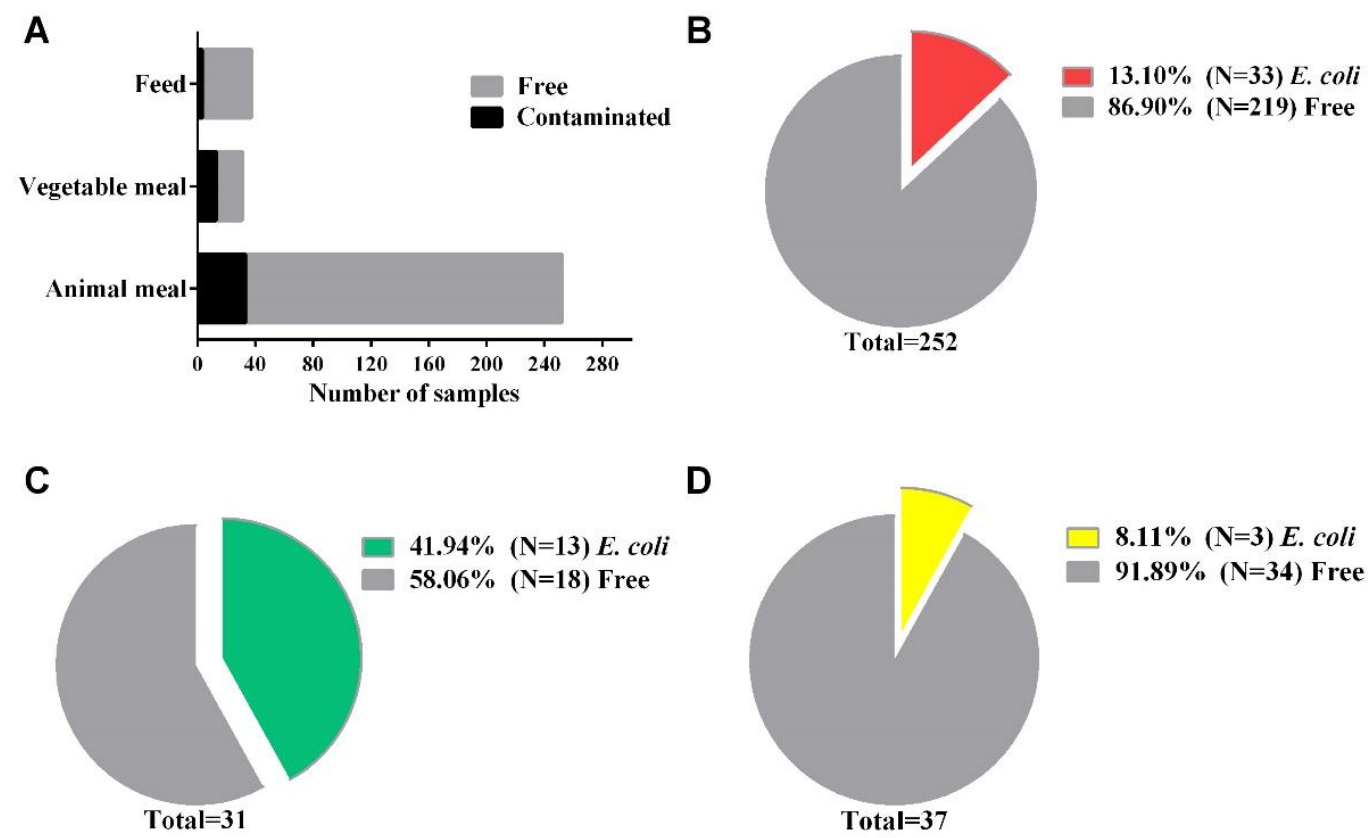

Figure 1. Distribution of feed and ingredient samples that tested positive for E. coli and negative. A. Total distribution of analyzed samples, Chi-square $(19.38,2), \mathrm{P}<0.0001$; B. Animal meals, Chi-square (7.509, 1), $\mathrm{P}<0.0061$; C. Vegetable meals, Chi-square $(9.323,1), \mathrm{P}<0.0023$; D. Feeds, Chi-square no significant difference.

The contamination of vegetable meal is difficult to measure, because it may occur during preharvest or post-harvest (Berry and Wells, 2016). According Berry and Wells (2016), pre-harvest contamination can be associated to organic fertilizer introduced naturally or artificially, feces of wild or domestic animals, water, soil or airborne particulate matters. Post-harvest by inadequate handling, storage, processing and transport (Berry and Wells, 2016). Although animal waste is usually more associated to contamination, it is cooked for a longer period 
and at high temperature (Brazil, 2008). However, thermal failure after processing, cooling, storage, transportation and handling, could be involved in the contamination found in our work.

The feed, as a ready product for animal consumption, must be free of pathogens. The study of Torres et al. (2011) attributed the contamination of feed to cooling after pellet process, storage and transportation. Other authors demonstrated the tolerance to adverse conditions of $E$. coli to survive in dry environments, such as dried corn (Dargatz et al., 2005), and organic fertilizer after the composting manure process (Gazal et al., 2015).
However, few samples of feed were positive for $E$. coli, the strains showed significant higher frequency of antimicrobial resistance than strains from vegetable and animal meals (Table 1). Most of the strains from feed had high values of resistance to cefazolin $(87.5 \%)$; ampicillin, chloramphenicol, amoxicillin + clavulanic acid and florfenicol (75\%); nalidixic acid (62.5\%); cefotaxime, sulfonamide, sulfazotrim, tetracycline, doxycycline, ciprofloxacin, enrofloxacin and norfloxacin (50\%); and ceftazidime $(37.5 \%)$. Over $90 \%$ of susceptibility was observed only for neomycin, gentamicin, nitrofurantoin and cefoxitin. No strain was susceptible to cefazolin.

Table 1. Relationship between antimicrobial resistance of Escherichia coli strains isolated from feed $(\mathrm{n}=8)$, animal meal $(\mathrm{n}=74)$, and vegetable meal $(\mathrm{n}=28)$

\begin{tabular}{|c|c|c|c|c|}
\hline Class & Antimicrobial & $\begin{array}{l}\text { Animal meal } \\
\mathrm{n}(\%)\end{array}$ & $\begin{array}{l}\text { Vegetable } \\
\text { meal n }(\%)\end{array}$ & $\begin{array}{l}\text { Feed } \\
\mathrm{n}(\%)\end{array}$ \\
\hline \multirow{2}{*}{ Amphenicols } & Chloramphenicol (CLO) $30 \mu \mathrm{g}$ & $2(2.7)^{\mathrm{a}}$ & $0(0.0)^{\mathrm{ab}}$ & $6(75)^{b}$ \\
\hline & Florfenicol (FLF) $30 \mu \mathrm{g}$ & $3(4.1)^{\mathrm{a}}$ & $0(0.0)^{\mathrm{ab}}$ & $6(75)^{b}$ \\
\hline \multirow{4}{*}{ Quinolones } & Norfloxacin (NOR) $10 \mu \mathrm{g}$ & $0(0.0)^{\mathrm{a}}$ & $0(0.0)^{\mathrm{a}}$ & $4(50)^{\mathrm{a}}$ \\
\hline & Ciprofloxacin (CIP) $5 \mu \mathrm{g}$ & $1(1.4)^{\mathrm{a}}$ & $0(0.0)^{\mathrm{a}}$ & $4(50)^{\mathrm{a}}$ \\
\hline & Enrofloxacin (ENO) $5 \mu \mathrm{g}$ & $0(0.0)^{\mathrm{a}}$ & $0(0.0)^{\mathrm{a}}$ & $4(50)^{\mathrm{a}}$ \\
\hline & Nalidixic Acid (NAL) $30 \mu \mathrm{g}$ & $3(4.1)^{\mathrm{a}}$ & $3(10.7)^{\mathrm{a}}$ & $5(62.5)^{b}$ \\
\hline \multirow{2}{*}{ Aminoglycosides } & Gentamicin (GEN) $10 \mu \mathrm{g}$ & $0(0.0)^{\mathrm{a}}$ & $0(0.0)^{\mathrm{a}}$ & $0(0.0)^{\mathrm{a}}$ \\
\hline & Neomycin (NEO) $30 \mu \mathrm{g}$ & $3(4.1)^{\mathrm{a}}$ & $3(10.7)^{\mathrm{a}}$ & $0(0.0)^{\mathrm{a}}$ \\
\hline Nitrofurans & Nitrofurantoin (NIT) $300 \mu \mathrm{g}$ & $5(6.8)^{\mathrm{a}}$ & $1(3.6)^{a}$ & $0(0.0)^{\mathrm{a}}$ \\
\hline \multirow{2}{*}{ Sulfonamides } & Sulfonamide (SUL) $300 \mu \mathrm{g}$ & $44(59.5)^{\mathrm{a}}$ & $20(71.4)^{\mathrm{a}}$ & $4(50)^{\mathrm{a}}$ \\
\hline & Sulfazotrim (SUT) $25 \mu \mathrm{g}$ & $8(10.8)^{\mathrm{a}}$ & $3(10.7)^{\mathrm{a}}$ & $4(50)^{b}$ \\
\hline \multirow{4}{*}{ Tetracyclines } & Doxycycline (DOX) $30 \mu \mathrm{g}$ & $2(2.7)^{\mathrm{a}}$ & $1(3.6)^{\mathrm{ab}}$ & $4(50)^{b}$ \\
\hline & Tetracycline (TET) $30 \mu \mathrm{g}$ & $3(4.1)^{\mathrm{a}}$ & $2(7.1)^{\mathrm{ab}}$ & $4(50)^{b}$ \\
\hline & Ampicilin (AMP) $10 \mu \mathrm{g}$ & $14(18.9)^{\mathrm{a}}$ & $11(39.3)^{b}$ & $6(75)^{b}$ \\
\hline & $\begin{array}{l}\text { Amoxacillin+ Clavulanic acid } \\
\text { (AMC) } 30 \mu \mathrm{g}\end{array}$ & $5(6.8)^{\mathrm{a}}$ & $1(3.6)^{\mathrm{a}}$ & $6(75)^{b}$ \\
\hline \multirow[t]{4}{*}{$\beta$-Lactams } & Cefazolin (CFZ) $30 \mu \mathrm{g}$ & $31(41.9)^{\mathrm{a}}$ & $23(82.1)^{b}$ & $7(87.5)^{\mathrm{ab}}$ \\
\hline & Cefotaxime (CTX) $30 \mu \mathrm{g}$ & $4(5.4)^{\mathrm{a}}$ & $12(42.9)^{\mathrm{b}}$ & $4(50)^{b}$ \\
\hline & Cefoxitin (CFO) $30 \mu \mathrm{g}$ & $3(4.1)^{\mathrm{a}}$ & $3(10.7)^{\mathrm{a}}$ & $0(0.0)^{\mathrm{a}}$ \\
\hline & Ceftazidime (CAZ) $30 \mu \mathrm{g}$ & $2(2.7)^{\mathrm{a}}$ & $10(35.7)^{\mathrm{b}}$ & $3(37.5)^{\mathrm{ab}}$ \\
\hline
\end{tabular}

Statistical difference between the resistances of isolates represented by the letter on the lines (a, b), with $p$ value $<$ 0.05 , Chi-square test. $\mathrm{n}=$ number of resistant isolates.

The resistance for ampicillin was lower in animal $(18.9 \%)$ and vegetable meals $(39.3 \%)$. Further, both strains from animal and vegetable meals were susceptible, respectively, to tetracycline (95.9\% and $92.9 \%)$ and to nalidixic acid $(95.9 \%$ and $89.3 \%$ ). High resistance rates for inputs were observed for sulfonamide and cefazolin, respectively, in animal meal $(59.5 \%$ and $41.9 \%)$, and vegetable meal $(71.4 \%$ and $82.1 \%)$.
Tetracycline was widely used prophylactically in broiler feed until its prohibition in Brazil (Brazil, 2009). Therefore, amphenicols, $\beta$-lactams (benzilpenicilamics and cephalosporins), quinolones and systemic sulfonamides are allowed exclusively in antimicrobial products for veterinary utilization (Brazil, 2009). The high levels of resistance to these drugs observed in our work may indicate that they are still being applied. Another possibility is a consolidate resistance of bacteria or a co-selection by other 
unrelated antimicrobial (Hanon et al., 2015; Davis et al., 2011; Lima-Filho et al., 2013). Products containing chloramphenicol and nitrofurans were also completely banned in Brazil. Low resistance to these drugs occurred for animal and vegetable meals, but feed isolates had $75 \%$ of resistance to chloramphenicol. According to Hanon et al. (2015), resistance to chloramphenicol, but not to florfenicol, could be related to some genes founded in integrons and plasmids harboring other resistance genes.

These alarming levels of resistance of E. coli isolated from animal meal can be associated to the selection by administration of antimicrobial agents against infections in poultry production or medicines used as therapeutic form soon after birth (Hanon et al., 2015). Resistance of strains from vegetable meal may be associated with contamination from environmental sources, as naturally resistant strains, or associated with the industry. In the second situation, the mixture of raw materials from different regions of a state or a country, and the storage or processing of the feed may have increased the contamination.

In Table 2 it is possible to observe an overview of $E$. coli isolates, without considering the type of food. The profile demonstrates that the most of strains, around $61 \%$, were resistant to no more than two antibiotics. Multi-drug resistance (resistance to three or more classes of drugs) was observed in $18 \%$ of total strains (20/110). Considering each set of supplies, we observed $12.2 \%(9 / 74)$ of multi-drug resistance for animal meal, with 0.093 mean MAR index; $17.9 \%$ $(5 / 28)$ for vegetable meal, with 0.174 mean MAR index; and 75\% (6/8) for feed, with 0.467 mean MAR index. According to Krumperman (1983), E. coli with MAR over 0.2 could act as a reservoir of resistance genes. Considering the mean index observed, the strains isolated from feed can be harboring genes coding for resistance or may be able to increase the expression of genes coding for mechanisms of evasion (Nikaido, 2009). The main factor in the development of multiple resistance is related to the ability of bacteria to acquire and disseminate exogenous genes. Even in the absence of selective pressure of specific antimicrobial drug, some specific resistance genes can be maintained due to the association with the genes encoding resistance to other antimicrobial agents currently used in the production of broilers (Diarra et al., 2007).

Table 2. Profile of all Escherichia coli $(\mathrm{n}=110)$ isolated from feed and ingredients evaluated in the antimicrobial susceptibility test and the frequency of Multiple Antibiotic Resistance (MAR)

\begin{tabular}{l|lll}
\hline Number of antimicrobials resistance & Number of E. coli strains & $\begin{array}{l}\text { Frequency of } \\
\text { resistance (\%) }\end{array}$ & MAR \\
\hline 0 & 16 & 14.54 & 0 \\
1 & 27 & 24.54 & 0.053 \\
2 & 24 & 21.81 & 0.105 \\
3 & 18 & 16.36 & 0.158 \\
4 & 9 & 8.18 & 0.211 \\
5 & 5 & 4.45 & 0.263 \\
6 & 3 & 2.75 & 0.316 \\
7 & 1 & 0.90 & 0.368 \\
8 & 3 & 2.75 & 0.421 \\
13 & 2 & 0.90 & 0.684 \\
14 & 1 & 0.90 & 0.737 \\
15 & 1 & 0.90 & 0.789 \\
\hline
\end{tabular}

The MAR index ranges from zero to 0.789 , so the closer to one, the larger the resistance (Krumperman, 1983). The data about MAR index according the type of food is depicted in Figure 2. Animal meal had a significantly lower index when compared with vegetable and feed. 


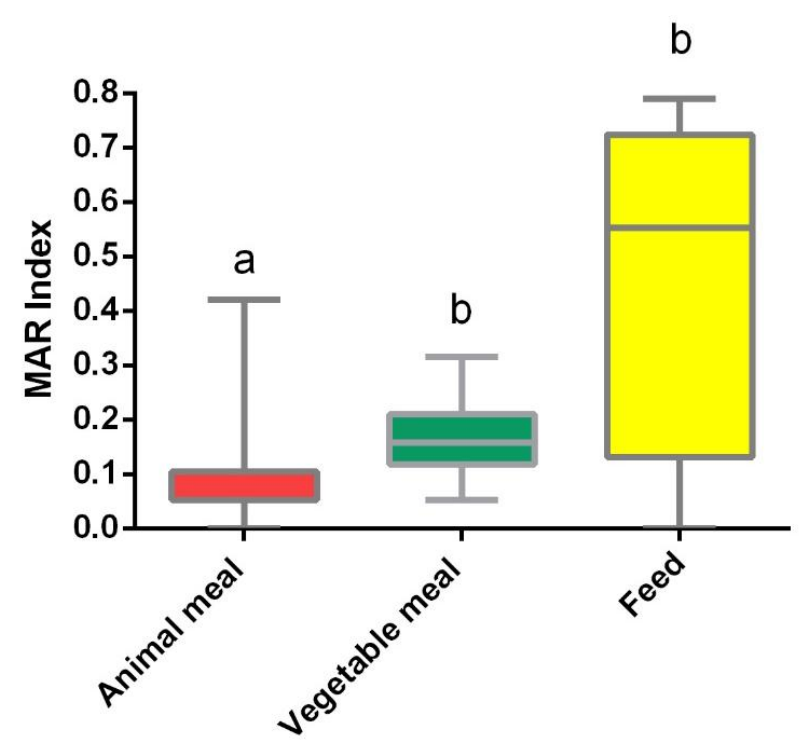

Figure 2. Multiple Antibiotic Resistance (MAR) Index of Escherichia coli isolates from food samples. Significant difference by Kruskal-Wallis test $(\mathrm{P}<0.05)$, Dunn's multiple comparisons test represented by letter.

Only six bacteria from animal meal accumulated the virulence gene predictors of APEC (Table 3): two isolates were positive for one gene (iutA or iss), three isolates were positive for two genes (iro $\mathrm{N}$ and iss) and one isolate was positive for four genes (iro $\mathrm{N}, o m p \mathrm{~T}, h l y \mathrm{~F}$ and $i u t \mathrm{~A}$ ). The last one, from meat meal, was also positive for the eae gene, being classified as E. coli Enteropathogenic (EPEC) atypical. In multiplex PCR for DEC, two isolates of feed and two isolates of animal meal were positive for the elt gene, being classified as $E$. coli enterotoxigenic (ETEC) heat-labile (LT).

Table 3. Origin, phylogenetic groups, virulence factors and genes related to avian pathogenic (APEC) and diarrheagenic (DEC) of Escherichia coli isolated from feed and ingredients

\begin{tabular}{|c|c|c|c|c|}
\hline Sample & Origin & $\begin{array}{l}\text { Phylogenetic } \\
\text { group }\end{array}$ & Virulence Factors & Genes related to pathotypes \\
\hline 1 & BMM & B1 & $\begin{array}{c}\text { eae } \mathrm{A}, \text { iro } \mathrm{N}, \text { omp } \mathrm{T}, \\
h l y \mathrm{~F}, \text { iut } \mathrm{A}\end{array}$ & EPEC (DEC) e APEC \\
\hline 5 & BMM & A & elt & ETEC (DEC) \\
\hline 6 & BMM & A & elt & ETEC (DEC) \\
\hline 106 & $\mathrm{~F}$ & A & elt & ETEC (DEC) \\
\hline 108 & $\mathrm{~F}$ & A & elt & ETEC (DEC) \\
\hline 63 & BMM & B1 & iroN, iss & APEC \\
\hline 64 & BMM & B1 & iro $\mathrm{N}$, iss & APEC \\
\hline 65 & BMM & B1 & iroN, iss & APEC \\
\hline 69 & BMM & B1 & iutA & APEC \\
\hline 73 & SMM & A & iss & APEC \\
\hline
\end{tabular}

BMM: bovine meat meal; SMM: swine meat meal; F: feed; iroN: salmoquelina the siderophore receptor; omp T: encoding outer membrane protein; hlyF: avian hemolysin; iutA: siderophore receptor of aerobactin gene; iss: serum resistance; eaeA: structural enteropathogenic E. coli, EPEC: elt: enterotoxin-producing gene of enterotoxigenic $E$. coli, ETEC.

We found one bacterium, from bovine meat meal, accumulating four genes associated with APEC and one gene associated with atypical EPEC. Even with the presence of four out of five
APEC virulence predictor genes, we cannot state that it is a pathogenic bacterium (Oliveira et al., 2015). To confirm this information, it would be necessary to inoculate it in one-day-old chicks 
and evaluate the development of an infection. However, the zoonotic potential of APEC should be considered, since the chicken is the primary host of this pathotype. Atypical EPEC does not harbor the bfp gene (Aranda et al., 2007) and it is reported to infect humans and animals, such as calves, monkeys, rabbits and dogs (Trabulsi et al., 2002). However, it appears to be less virulent than the typical EPEC, which is strongly related to diarrhea in children under one year old in Brazil (Aranda et al., 2007). Despite the presence of virulence factors, this isolate was sensitive to all antibiotics tested.

Two strains from feed were classified as ETEC LT. The elt gene is in transmissible plasmid and encodes a protein with structural similarity, functional and immunological to Cholera toxin produced by Vibrio cholerae O1, causing watery diarrhea followed by an imbalance of intestinal absorptive capacity (Phetkhajorn et al., 2014). Interestingly, these strains presented resistance for more than 13 antimicrobial drugs. The feed used in our research is composed by animal meal (avian origin), which can be the source of the contamination and the presence of elt gene.

APEC and DEC transmission to humans may occur from consumption of undercooked contaminated meat and egg (Johnson et al., 2008; Kunert Filho et al., 2015). Studies comparing $E$. coli isolated from avian origin and from extraintestinal infections of humans showed that the strains were indistinguishable based on the expression of virulence genes (Bauchart et al., 2010; Cunha et al., 2013; Koga et al., 2015). Studies about virulence genes in bacteria isolated from feed were not found in the literature, indicating that our work is the first report. Other studies evaluating the presence of genes related to APEC, DEC and ETEC were found for poultry with colibacillosis lesions and healthy animal feces (Jianguo et al., 2012), marketed chicken carcasses (Koga et al., 2015), in aviaries (Carvalho et al., 2015) and in organic fertilizers resulting from chicken manure composting (Gazal et al., 2015). The occurrence of the five gene predictors for APEC was verified in almost all studies. Most of these researches also verified the susceptibility of strains against antimicrobial agents and high resistance was observed to tetracycline, nalidixic acid and ampicillin.

The positive strains for virulence genes $(n=10)$ were assigned into four main phylogenetic groups (A, B1, B2 and D). Five bacteria showed to belong to the group A and five to the group B1 (Table 3). Although these phylogenetic groups are related to commensal strains, the presence of the virulence genes contributes directly to pathogenic characteristic, allowing more successful colonization in the host and ability to horizontally transfer and acquire genes (Pitout, 2012; Koga et al., 2015).

\section{CONCLUSIONS}

Contamination by $E$. coli was found in samples of feed and ingredients evaluated, especially in vegetable ingredients. Despite the low occurrence of virulence genes associated with APEC and DEC, the strains that harbored these genes were from animal meal or containing meat meal. Virulence genes in $E$. coli isolated in poultry feed are reported for the first time. The high frequency of antimicrobial resistance was mainly observed for sulfonamides and $\beta$-lactams classes, in strains from feed, a ready product for animal consumption, and from vegetable. Multidrug resistance bacteria were found in all inputs. The isolates belong to phylogenetic groups A and B1, characteristic of commensal E. coli, but can serve as reservoirs of virulence and antimicrobial resistance genes for animals and humans, acting as intestinal and extra-intestinal pathogens. The data cleared the potential risk of food safety and animal health of feed and ingredients. Contamination parameters for $E$. coli in raw materials and final products of animal feed can be used as a management control system.

\section{ACKNOWLEDGEMENTS}

Coordenação de Aperfeiçoamento de Pessoal de Nível Superior (CAPES) for granting the scholarship. The authors want to thank all rendering plants and cereal grain industries that provided the samples for the study. 


\section{REFERENCES}

AHMED, A.A.; SHIMAMOTO, T.; SHIMAMOTO, T. Molecular characterization of multidrug-resistant avian pathogenic Escherichia coli isolated from septicemic broilers. Int. J. Med. Microbiol., v.303, p.475-483, 2013.

ARANDA, K.R.S.; FABBRICOTTI, S.H.; FAGUNDES-NETO, U.; SCALETSKY, I.C.A. Single multiplex assay to identify simultaneously enteropathogenic, enteroaggregative, enterotoxigenic, enteroinvasive and Shigatoxinproducing Escherichia coli strains in Brazilian children. FEMS Microbiol. Lett., v.267, p.145150, 2007.

BAUCHART, P.; GERMON, P.; BRÉE, A. et al. Pathogenomic comparison of human extraintestinal and avian pathogenic Escherichia coli - search for factors involved in host specificity or zoonotic potential. Microbiol. Pathog., v.49, p.105-115, 2010.

BERRY, E.D; WELLS, J.E. Reducing foodborne pathogen persistence and transmission in animal production environments: challenges and opportunities. Microbiol. Spectr., v.4, p.1-18, 2016.

BRAZIL. Ministério da Agricultura, Pecuária e Abastecimento. Instrução Normativa, ${ }^{\circ} 34$, de 28 de maio de 2008. Regulamento Técnico da Inspeção Higiênico Sanitária e Tecnológica do Processamento de Resíduos de Animais e o Modelo de Documento de Transporte de Resíduos Animais. Disponível em: http://sistemasweb.agricultura.gov.br/sislegis/acti on/detalhaAto.do?method=visualizarAtoPortalM apa \&chave $=284275208$

BRAZIL. Ministério da Agricultura, Pecuária e Abastecimento. Instrução Normativa, n²6, de 9 de julho de 2009. Regulamento Técnico para a fabricação, o controle de qualidade, a comercialização e o emprego de produtos antimicrobianos de uso veterinário. Disponível em:

<http://sistemasweb.agricultura.gov.br/sislegis/ac tion/detalhaAto.do?method=visualizarAtoPortal Mapa\&chave $=1984822284>$. Acessado em: 27 set. 2017.
CARVALHO, D.; FINKLER, F.; GRASSOTTI, T.T. et al. Antimicrobial susceptibility and pathogenicity of Escherichia coli strains of environmental origin. Ciênc. Rural, v.45, p.1249-1255, 2015.

CERNA, J.F.; NATARO, J.P.; GARCIA, T.E. Multiplex PCR for detection of three plasmidborne genes of Enteroaggregative Escherichia coli strains. J. Clin. Microbiol., v.41, p.21382140, 2003.

CLERMONT, O.; BONACORSI, S.; BINGEN, E. Rapid and simple determination of the Escherichia coli phylogenetic group. Appl. Environ. Microbiol., v.66, p.4555-4558, 2000.

CUNHA, M.P.V.; MENÃO, M.C.; FERREIRA, A.J.P.; KNÖBL, T. A similaridade genética de Escherichia coli patogêncica para aves (APEC) com estirpes humanas e a resistência antimicrobiana justificam a preocupação sanitária em relação aos produtos de origem aviária? Rev. Educ. Cont. Vet. Med. Zootec. CRMV-SP, v.11, p.24-33, 2013.

DARGATZ, D.A.; STROHMEYER, R.A.; MORLEY, P.S. et al. Characterization of Escherichia coli and Salmonella enteric from cattle feed ingredients. Foodborne Pathog. Dis., v.2, p.341-347, 2005.

DAVIS, M.F.; PRICE, L.B.; MENG-HSIN, L.C.; SILBERGELD, E.K. An ecological perspective on U.S. industrial poultry production: the role of anthropogenic ecosystems on the emergence of drug-resistant bacteria from agricultural environments. Curr. Opin. Microbiol., v.14, p.244-250, 2011.

DHO-MOULIN, M.; FAIRBROTHER, J.M. Avian pathogenic Escherichia coli (APEC). Vet. Res., v.30, p.299-316, 1999.

DIARRA, M.S.; SILVERSIDES, F.G.; DIARRASSOUBA, F. et al. Impact of feed supplementation with antimicrobial agents on growth performance of broiler chickens, Clostridium perfringens and Enterococcus counts, and antibiotic resistance determinants in Escherichia coli isolates. Appl. Environ. Microbiol., v.73, p.6666-6676, 2007. 
GAZAL， L.E.S.; PUÑO-SARMIENTO， J.J.; MEDEIROS, L.P. et al. Presence of pathogenicity islands and virulence genes of extraintestinal pathogenic Escherichia coli (ExPEC) in isolates from avian organic fertilizer. Poult. Sci., v.94, p.3025-3033, 2015.

GEORNARAS, I.; HASTINGS, J.W.; VON HOLY, A. Genotypic analysis of Escherichia coli strains from poultry carcasses and their susceptibilities to antimicrobial agents. Appl. Environ. Microbiol., v.67, p.1940-1944, 2001.

HANON, J.B.; JASPERS, S.; BUTAYE, P. et al. A trend analysis of antimicrobial resistance in commensal Escherichia coli from several livestock species in Belgium (2011-2014). Prev. Vet. Med., v.122, p.443-452, 2015.

JIANGUO, Y.; WEIHUA, C.; HUAFU, W.; WEI, Z. Antimicrobial susceptibility and virulence factors of Escherichia coli isolates obtained from faeces samples of chickens in east China. Afr. J. Microbiol. Res., v.6, p.1591-1596, 2012.

JOHNSON， T.J.; WANNEMUEHLER，Y.; DOETKOTT, C. et al. Identification of minimal predictors of avian pathogenic Escherichia coli virulence for use as a rapid diagnostic tool. $J$. Clin. Microbiol., v.46, p.3987-3996, 2008.

KOGA V.L.; SCANDORIEIRO, S.; VESPERO, E.C. et al. Comparison of antibiotic resistance and virulence factors among Escherichia coli isolated from conventional and free-range poultry. Biomed. Res. Int., v.2015, 2015.

KRUMPERMAN, P.H. Multiple antibiotic resistance indexing of Escherichia coli to identify high risk sources of fecal contamination of foods. Appl. Environ. Microbiol., v.46, p.165$170,1983$.

KUNERT FILHO, H.C.; BRITO, K.C.T.; CAVALLI, L.S.; BRITO, B.G. Avian Pathogenic Escherichia coli (APEC) - an update on the control. In: MÉNDEZ-VILAS, A. (Ed.). The battle against microbial pathogens: basic science, technological advances and educational programs. Badajoz, Espanha: Formatex Research Center, 2015. p.598-618.
LIMA-FILHO, J.V.; MARTINS, L.V.; NASCIMENTO, D.C.O. et al. Zoonotic potential of multidrug-resistant extraintestinal pathogenic Escherichia coli obtained from healthy poultry carcasses in Salvador, Brazil. Braz. J. Infect. Dis., v.17, p.54-61, 2013.

METHODS for dilution antimicrobial susceptibility tests for bacteria that grow aerobically, Approved Standard. 9.ed. M07-A9 document. Wayne: CLSI, 2012.

NIKAIDO, H. Multidrug resistance in bacteria. Annu. Rev. Biochem., v.78, p.119-146, 2009.

OLIVEIRA, A.L.; ROCHA, D.A.; FINKLER, F. et al. Prevalence of ColV plasmid-linked genes and in vivo pathogenicity of avian strains of Escherichia coli. Foodborne Pathog. Dis., v.12, p.679-685, 2015.

PATON, A.W.; PATON, J.C. Detection and characterization of Shiga Toxigenic Escherichia coli by using multiplex PCR Assays for stxl, stx2, eaeA, Enterohemorrhagic E. coli hlyA, $r f b_{\mathrm{O} 111}$, and $r f b_{\mathrm{O} 157}$. J. Clin. Microbiol., v.36, p.598-602, 1998.

PHETKHAJORN, S.; SIRIKAEW, S.; RATTANACHUAY, P.; SUKHUMUNGOON, P. Most probable number-polymerase chain reaction-based quantification of enterotoxigenic Escherichia coli from raw meats in southern Thailand. Southeast Asian J. Trop. Med. Public Health, v.45, p.1385-1391, 2014.

PITOUT, J.D.D. Extraintestinal pathogenic Escherichia coli: a combination of virulence with antibiotic resistance. Front. Microbiol., v.3, p.17, 2012.

TORRES, G.J.; PIQUER, F.J.; ALGARRAA, L. et al. The prevalence of Salmonella enterica in Spanish feed mills and potential feed-related risk factors for contamination. Prev. Vet. Med., v.98, p.81-87, 2011.

TRABULSI, L.R.; KELLER, R.; GOMES, T.A.T. Typical and atypical Enteropathogenic Escherichia coli. Emerg. Infect. Dis., v.8, p.508513, 2002. 